\title{
KONTRIBUSI LINGKUNGAN KELUARGA DAN AKTIVITAS FISIK TERHADAP KESEGARAN JASMANI ANAK TUNAGRAHITA
}

\author{
Merlina Sari \\ Universitas Islam Riau \\ merlinasari@edu.uir.ac.id
}

\begin{abstract}
ABSTRAK
Penelitian ini bertujuan untuk mengungkapkan kontribusi faktor lingkungan keluarga dan aktivitas fisik terhadap kesegaran jasmani anak tunagrahita pada SLB Negeri Pekanbaru Riau. Penelitian ini bersifat kuantitatif dengan menggunakan penelitian korelasi, di sekolah SLB Negeri Pembina Pekanbaru tahun ajaran 2011/2012 dengan sampel 30 orang anak tunagrahita. Tehnik pengambilan sampel dilakukan dengan carapurposive rondom sampling. Hasil analisis data menunjukkan pada pengujian hipotesis pertama terdapat kontribusi yang signifikan antara faktor lingkungan keluarga terhadap kesegaran jasmani anak tunagrahita sebesar 14,44\%. Pada pengujian hipotesis kedua menunjukkan bahwa terdapat kontribusi yang signifikan antara aktivitas fisik dengan kesegaran jasmani anak tunagrahita sebsar $15,76 \%$. Pada pengujian hipotesis Ketiga menunjukkan bahwa terdapat kontribusi yang signifikan antara faktor lingkungan keluarga dan aktivitas fisik secara bersama-sama dengan kesegaran jasmani anak tunagrahita sebesar 24,70. Kesimpulan penelitian ini adalah untuk dapat menjadi sehat dan bugar yang berkualitas tidak cukup hanya dengan berolahraga saja tetapi juga lingkungan keluarga yang kondusif serta mendukung anak dalam meniti perkembangannya.
\end{abstract}

Kata Kunci: Lingkungan Keluarga, Aktifitas Fisik, Tunagrahita

\section{PENDAHULUAN}

Pendidikan merupakan salah satu cara untuk menuju kesuksesan bagi seseorang dimasa depan karena pendidikan adalah merupakan investasi jangka panjang yang hasilnya akan dituai kelak dikemudian hari. Dengan demikian pendidikan mempunyai peran yang sangat penting bagi kelangsungan suatu bangsa, karena berkaitan langsung dengan pembangunan kualitas sumber daya manusia.

Depdiknas (2003:1) Menyatakan penyelenggaraan program pendidikan jasmani hendaknya mencerminkan karakteristik program pendidikan jasmani itu sendiri, yaitu "Developmentally Appropriate Pracitice (DAP). Artinya bahwa tugas ajar yang disampaikan harus memperhatikan perubahan kemampuan atau kondisi fisik anak dan dapat membantu perubahan tersebut.Dengan demikian tugas ajar harus sesuai dengan tingkat perkembangan dan tingkat kematangan anak didik yang diajarkan.

Dalam kurikulum 1994, Pendidikan jasmani dan kesehatan merupakan bagian integral dari pelaksanaan proses pembelajaran sikap, Prilaku dan watak peserta didik dalam kehidupan bermasyarakat agar dapat hidup mandiri. mampu berkompetisi dan berani mempertahankan kebenaran serta membentuk sifat kejujuran. Program pendidikan khususnya pendidikan olahraga harus dilandasi dengan visi dan misi yang jelas dan berpihak kepada masyarakat luas sebagai pengguna jasa pendidikan, sehingga kita harus berpikir keras dalam membuat beberapa kajian dan pelajaran yaitunya pelajaran pendidikan olahraga dan kesehatan. 
Anak bekelainan mental Tunagrahita atau Intellectual Disability disebut juga anak yang memiliki kecerdasan mental dibawah normal. Kelainan atau ketunaan pada aspek fisik, mental, maupun sosial yang dialami oleh seseorang akan membawa konsekuensi tersendiri bagi penyandangnya, baik secara keseluruhan ataupun sebagian, baik yang bersifat objektif maupun subjektif kondisi kelainan yang disandang seseorang ini akan memberikan dampak kurang menguntungkan pada kondisi psikologis maupun psikososialnya. Pada gilirannya kondisi tersebut dapat menjadi hambatan yang berarti bagi penyandang kelainan dalam meniti tugas perkembangannya sehingga berdampak pada kesegaran jasmaninya.

Kesegaran jasmani anak berkelainan khususnya anak tunagrahita dipengaruhi oleh beberapa faktor, antara lain, faktor lingkungan keluarga, lingkungan masyarakat, faktor genetik (keturunan), faktor tingkat pengetahuan orang tua, status gizi, aktifitas fisik, sarana dan prasarana serta faktor ekonomi keluarga.

Kondisi anak berkelainan semakin tidak menguntungkan ketika lingkungan keluarga anak penyandang kelainan tidak memberikan respons yang positif dalam menyikapi kelainan anak.Memang kelainan yang dialami oleh anak sering kali menimbulkan masalah bagi lingkungannya.Kehadirannya secara langsung atau tidak langsung mengundang berbagai dimensi sikap dan tanggapan lingkungan terhadap kondisi anak berkelainan terutama lingkungan keluarga. Apabila sikap dan tanggapan lingkungan keluarga terhadap anak kurang positif dan tidak memandang sosok anak berkelainan sebagai individu yang mempunyai harkat sebagaimana manusia normal lainnya karna ketidak sempurnaannya, maka hal itu dapat menyudutkan keberadaannya ditengah-tengah masyarakat normal terutama pemberdayaan untuk melakukan fungsi kehidupan. Dari semua itu tentu saja akan menghambat perkembangan dan kesegaran jasmani anak berkelainan khususnya tunagrahita.

Faktor genetik (keturunan) diduga sebagai penyebab terjadinya ketunagrahitaan masih sulit dipastikan kontribusinya sebab para ahli sendiri mempunyai formulasi yang berbeda-beda mengenai keturunan sebagai penyebab ketunagrahitana. Kirk dalam Efendi misalnya, memberikan etimasi bahwa 80-90\% keturunan memberikan sumbangan terhadap terjadinya ketunagrahita.

Latar belakang pendidikan dan tingkat pengetahuan orang tua, juga cukup berpengaruh dengan tingkat kesegaran jasmani anak tunagrahita. Terbatasnya tingkat pengetahuan orang tua mengenai prilaku hidup sehat, dikhawatirkan juga mempengaruhi tingkat kesegaran jasmani siswa. Minat siswa untuk melakukan aktivitas fisik sangat dipengaruhi lingkungan keluarga. Pengetahuan dipengaruhi oleh beberapa yang dapat diperoleh dari pendidikan formal maupun informal, jadi pengetahuan sangat erat hubungannya dengan pendidikan, Pendidikan yang cukup dipandang dapat membantu orang tua dalam hal pengetahuan mengenai pemenuhan kecukupan gizi dan praktik pengasuhan anak untuk mencapai tingkat kesegaran jasmani anak yang baik.

Faktor status gizi, jika status gizi anak tunagrahita rendah tentu kesegaran jasmaninya rendah. Gizi yang kurang atau buruk pada anak yang mempunyai kelainan dapat berakibat terganggunya pertumbuhan jasmani dan kecerdasannya. Jika pertumbuhan jasmani terhambat, maka kesegaran jasmani tidak dapat berkembang dengan baik.

Aktifitas jasmani dan olahraga bagi para penyandang anak tunagrahita tidak jauh berbeda dengan anak normal. Karakteristik pembelajaran umum juga sama, yang khususnya adalah bahwa mereka lambat dalam menerima informasi. Akitivitas fisik anak tunagrahita baik dilingkungan keluarga maupun disekolah sangat memberikan 
warna terhadap kesegaran jasmani anak tunagrahita, Aktivitas fisik yang dilakukan oleh anak tunagrahita tentu saja tidak lepas dari pengawasan orang tua dalam melakukan aktivitas sehari-harinya misalnya program perawatan diri sendiri, agar lebih fungsional program tersebut dapat dipecah dalam berbagai unit prilaku pendukung antara lain mengancingkan baju, memegang sendok, menggosok gigi dan lain-lain.

Faktor yang berhubungan dengan kesegaran jasmani anak tunagrahita berkelainan adalah faktor ekonomi keluarga. Faktor ini cukup memberikan pengaruh terhadap kesegaran jasmani anak. Logikanya dengan keadaan ekonomi yang baik, maka tentu saja kecukupan zat gizi akan mudah terpenuhi dalam proses tumbuh kembangnya anak.

Faktor lain yang juga mempunyai pengaruh terhadap kesegaran jasmani anak tunagrahita adalah faktor sarana dan prasarana. Sarana pendidikan jasmani adalah segala sesuatu yang dapat digunakan dan dimanfaatkan dalam pendidikan jasmani, sedangkan prasarana adalah segala sesuatu yang dapat mempermudah dan memperlancar kegiatan pendidikan jasmani yang bersifat relatif permanen atau susah dipindah-pindahkan. Semua ini dimanfaatkan untuk mendukung keberhasilan dalam penyelenggaraan pengembangan kesegaran jasmani anak tunagrahita.

\section{METODE PENELITIAN}

Penelitian ini digolongkan pada jenis penelitian kuantitatif dengan menggunakan rancangan penelitian korelasional, bertujuan untuk menyelidiki seberapa jauh hubungan variabel-variabel yang diperoleh berkaitan dengan variabel lain berdasarkan kepada besarnya koefisien korelasi.

Populasi dalam penelitian ini adalah seluruh siswa yang berada di SLB Negeri Pekanbaru Riau yaitu SLB Negeri Pembina adapun jumlah Siswa SLB Negeri Pembina dengan jumlah 117 dengan laki-laki 63 dan perempuan 54. Sampel dalam penelitian ini ditetapkan hanya siswa tunagrahita yang laki-laki yang berjumlah 30 dengan teknik purposive rondom sampling.

Adapun Instrumen penelitian masing-masing variabel diuraikan sebagai berikut:

1. Kesegaran Jasmani

Tes kesegaran jasmani yang digunakan adalah tes kesegaran jasmani yang dikembangkan Cooper adalah tes 12 menit. Pada tes ini jarak yang di tempuh oleh peserta tidak ditentukan, yang ditentukan adalah waktu tempuh yaitu 12 menit selanjutnya jarak tempuh di ukur setelah peserta tes berlari 12 menit. Alat dan Fasilitas yang diperlukan dalam tes 12 menit ini, Lintasan 100 meter yang datar dan Terbuka, Pluit, Nomor dada, Kapur, Stopwatch, Formulir Tes, Guru serta Tenaga Kesehatan.

2. Faktor Lingkungan Keluarga

Sesuai dengan maksud dan tujuan dalam penelitian ini, maka pengumpulan data untuk faktor lingkungan keluarga dilakukan dengan Angket.

\section{HASIL DAN PEMBAHASAN}

Pengolahan data penelitian disajikan secara berurutan dapat dilihat pada tabel sebagai berikut:

Tabel 1. Rerata Hitung dan Standar Deviasi Data Penelitian

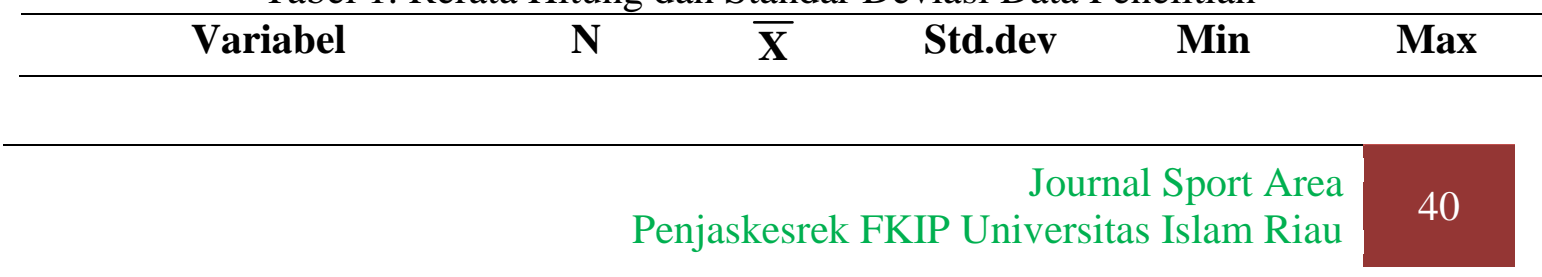




\begin{tabular}{lccccc} 
Lingkungan Keluarga & 30 & 88,67 & 3.77 & 83 & 96 \\
\hline Aktifitas Fisik & 30 & 88,03 & 5,15 & 80 & 98 \\
\hline Kesegaran Jasmani & 30 & 1826,45 & 538,41 & 834,3 & 2701 \\
\hline
\end{tabular}

Untuk lebih jelasnya gambaran keadaan masing-masing data dalam kelompok dapat dilihat deskripsi sebagai berikut:

\section{Faktor Lingkungan Keluarga}

Analisis deskriptif variabel Faktor Lingkungan Keluarga dengan 30 responden, diperoleh rerata hitung $=88,67$, standar deviasi $=3,77$, nilai minimum $=83$ dan nilai maksimum $=96$. Jelasnya dapat dilihat pada tabel berikut:

Tabel 2. Distribusi Frekuensi Faktor Lingkungan Keluarga

\begin{tabular}{ccc}
\hline Kelas Interval & Frekuensi & Persentase(\%) \\
\hline $83-84$ & 3 & 10 \\
\hline $85-86$ & 9 & 30 \\
\hline $87-88$ & 5 & 16.67 \\
\hline $89-90$ & 3 & 10 \\
\hline $91-92$ & 4 & 13.33 \\
\hline $93-94$ & 3 & 10 \\
\hline $95-96$ & 3 & $\mathbf{1 0 0 \%}$ \\
\hline Jumlah & $\mathbf{3 0}$ &
\end{tabular}

Berdasarkan tabel di atas dapat dilihat persentase faktor lingkungan keluarga tertinggi terdapat pada kelas interval kedua yaitu 30\%. Sedangkan persentase data terendah terdapat pada kelas interval pertama, keenam, dan ketujuh, sebesar $10 \%$. Untuk lebih jelasnya dapat dilihat pada grafik di bawah ini.

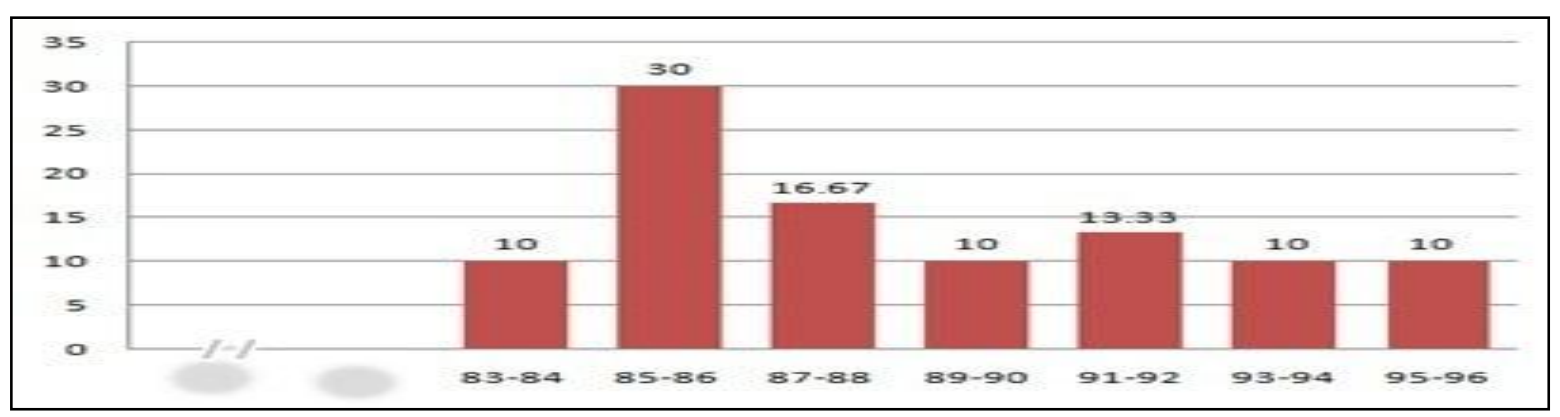

Grafik Data Faktor Lingkungan Keluarga

\section{Aktivitas Fisik}

Analisis variabel aktivitas fisik diperoleh rerata hitung $=88.03$, standar deviasi $=5.15$, nilai minimum $=80$ dan nilai maksimum $=98$. Untuk lebih jelasnya dapat dilihat pada tabel sebagai berikut :

Tabel 3. Distribusi Frekuensi Data Aktivitas Fisik

\section{Kelas Interval}

Frekuensi

Persentase $(\%)$ 


\begin{tabular}{ccc}
$80-83$ & 5 & 16.67 \\
\hline $84-87$ & 10 & 33.33 \\
\hline $88-91$ & 7 & 23.33 \\
\hline $92-95$ & 5 & 16.67 \\
\hline $96-99$ & 3 & 10 \\
\hline Jumlah & $\mathbf{3 0}$ & $\mathbf{1 0 0 \%}$
\end{tabular}

Berdasarkan tabel distribusi frekuensi di atas, dapat dilihat persentase data aktivitas fisik tertinggi terdapat pada kelas interval kedua.Sedangkan persentase data terendah terdapat pada kelas interval kelima.Untuk lebih jelasnya bisa dilihat pada grafik di bawah ini.

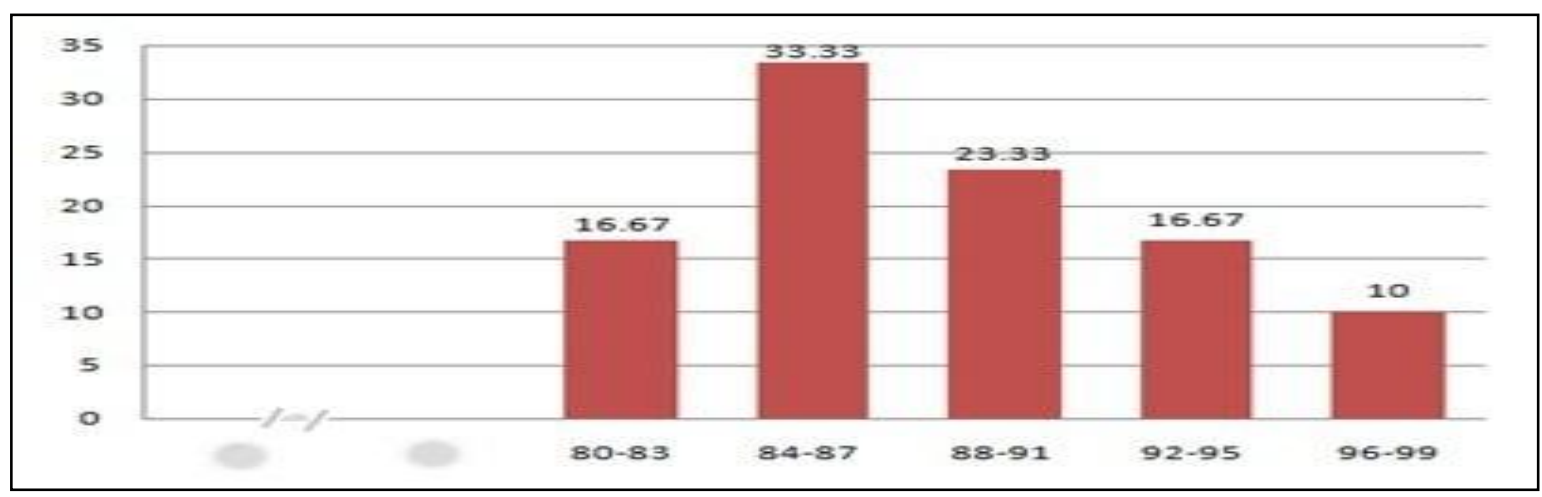

Grafik Data Aktivitas fisik

\section{Kesegaran Jasmani}

Analisis variabel Kesegaran Jasmanidperoleh rerata hitung $=1826.45$ standar deviasi $=538.41$, nilai minimum $=834.3$ dan nilai maksimum $=2701$. Untuk lebih jelasnya dapat dilihat pada tabel sebagai berikut:

Tabel 4. Distribusi Frekuensi Data Kesegaran Jasmani

\begin{tabular}{ccc}
\hline Kelas Interval & Frekuensi & Persentase(\%) \\
\hline$<1.608$ & 13 & 43.33 \\
\hline $1.609-2.011$ & 8 & 26.67 \\
\hline $2.212-2.413$ & 2 & 6.67 \\
\hline $2.414-2.815$ & 7 & 23.33 \\
\hline$>2.815$ & 0 & 0 \\
\hline Jumlah & $\mathbf{3 0}$ & $\mathbf{1 0 0 \%}$ \\
\hline
\end{tabular}

Berdasarkan tabel distribusi frekuensi di atas, dapat dilihat persentase data Kesegaran Jasmani tertinggi terdapat pada kelas interval pertama.Sedangkan persentase data terendah terdapat pada kelas interval kelima.Untuk lebih jelasnya bisa dilihat pada grafik dibawah ini: 


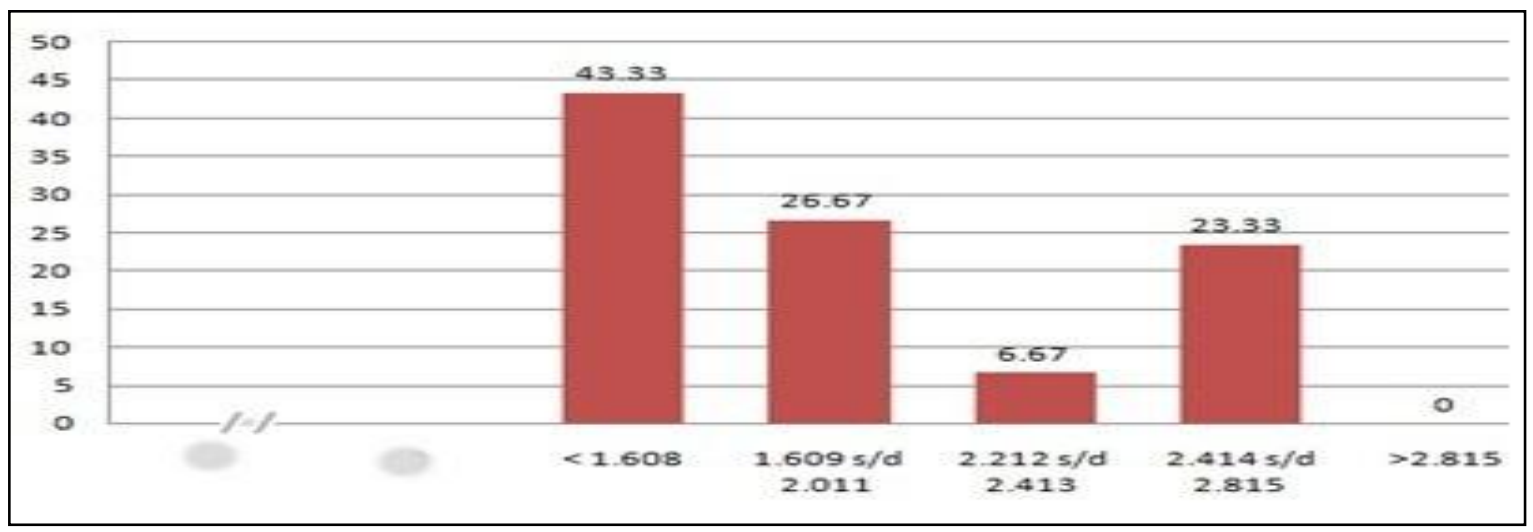

Grafik Data Kesegaran Jasmani

Pengolahan dan analisis dilakukan untuk mengetahui kontribusi faktor lingkungan keluarga dan aktivitas fisik terhadap Kesegaran Jasmani. Uji statistik yang digunakan adalah uji regresi pada taraf signifikansi $0.05 \alpha$. Untuk lebih jelasnya akan disajikan secara berurutan sebagai berikut:

\section{Faktor Lingkungan Keluarga Memberikan Kontribusi Yang Berarti Terhadap Kesegaran Jasmani}

Hasil analisis menunjukkan bahwa faktor lingkungan keluarga (X1) memiliki hubungan yang signifikan serta memberikan kontribusi yang berarti terhadap Kesegaran Jasmani. Pada tabel analisis korelasi data penelitian diperoleh koefisien korelasi faktor lingkungan keluarga terhadap Kesegaran Jasmani $r_{x 1 y}=0,380$ dengan $\mathrm{t}_{\text {hitung }}=2,17>\mathrm{t}_{\text {tabel }}=1,70$ menyatakan bahwa terdapat hubungan yang signifikan antar kedua variabel. Nilai persamaan regresi dapat digambarkan sebagai berikut $\widehat{Y}=-$ 2991,66+54,34, dengan $F_{\text {hitung }} 4,75>F_{\text {tabel }} 4,20$. Selanjutnya berdasarkan analisis linearitas regresi diperoleh nilai $\mathrm{f}_{\text {hitung }} 0,78<\mathrm{f}_{\text {tabel }} 2,34$. Hal ini menyatakan bahwa data berada dalam keadaan linear.Dengan demikian hipotesis yang diajukan (Ha) dapat diterima.Untuk lebih jelasnya dapat dilihat pada tabel di bawah ini.

Selanjutnya diperoleh koefesien determinasi melalui koefesien korelasi dikuadratkan $\left(\mathrm{r}^{2}\right)=(0,380)^{2}$ sebesar 0,1444 . Artinya bahwa variabel faktor lingkungan keluarga sebagai independent variabel memberikan kontribusi sebesar 14,44\% terhadap dependent variabel yaitu Kesegaran Jasmani siswa SLB Negeri Pekanbaru Riau. Sedangkan sisanya diterangkan oleh variabel lain.

\section{Aktivitas Fisik Memberikan Kontribusi Yang Berarti Terhadap Kesegaran Jasmani}

Hasil analisis menunjukkan bahwa aktivitas fisik (X2) memiliki hubungan yang signifikan serta memberikan kontribusi yang berarti terhadap Kesegaran Jasmani. Pada tabel analisis korelasi data penelitian diperoleh koefisien korelasi aktivitas fisik terhadap Kesegaran Jasmanisebesar $r_{\mathrm{x} 2 \mathrm{y}}=0,397$ dengan $t_{\text {hitung }}=2,29>t_{\text {tabel }}=1,70$ menyatakan bahwa terdapat hubungan yang signifikan antar kedua variabel. Nilai persamaan regresi dapat digambarkan sebagai berikut $\mathrm{Y}=-1833,88+41,58 \mathrm{x}_{2}$, dengan $F_{\text {hitung }} 5,26>F_{\text {tabel }} 4,20$. Selanjutnya berdasarkan analisis linearitas regresi diperoleh nilai $\mathrm{f}_{\text {hitung }} 1,05<\mathrm{f}_{\text {tabel }} 2,51$. Hal ini menyatakan bahwa data berada dalam keadaan linear.Dengan demikian hipotesis yang diajukan (Ha) dapat diterima. 
Selanjutnya diperoleh koefesien determinasi melalui koefesien korelasi dikuadratkan $\left(\mathrm{r}^{2}\right)=(0,397)^{2}$ sebesar 0,1576 . Artinya bahwa variabel aktivitas fisik sebagai independent variabel memberikan kontribusi sebesar $15,76 \%$ terhadap dependent variabel yaitu Kesegaran Jasmani Anak SLB Negeri. Sedangkan sisanya diterangkan oleh variabel lain.

\section{Faktor Lingkungan Keluarga dan Aktivitas Fisik Secara Bersama-sama Memberikan Kontribusi yang Berarti Terhadap Kesegaran Jasmani}

Analisis ke dua variabel $\left(\mathrm{X}_{1}\right.$ dan $\left.\mathrm{X}_{2}\right)$ menunjukkan bahwa variabel faktor lingkungan keluarga dan variabel aktivitas fisik secara bersama-sama memiliki hubungan yang signifikan serta memberikan kontribusi yang berarti terhadap Kesegaran Jasmani. Pada tabel correlation analisis diperoleh koefisien korelasi variabel faktor lingkungan keluarga dan aktivitas fisik terhadap Kesegaran Jasmani sebesar $\mathrm{r}_{\mathrm{x} 12 \mathrm{y}}$ $=0,497>r_{\text {tabel }}$ 0,361. Ini menunjukkan hubungan yang signifikan antara faktor lingkungan keluarga $\left(\mathrm{X}_{1}\right)$ dan aktivitas fisik $\left(\mathrm{X}_{2}\right)$ secara bersama-sama terhadap Kesegaran Jasmani (Y). Berdasarkan kekuatan hubungan variabel di atas, maka nilai persamaan regresi adalah sebagai berikut $\hat{\mathrm{Y}}=-6134,09+50,89 \mathrm{X}_{1}+39,17 \mathrm{X}_{2} \hat{\mathrm{Y}}$ dengan $F_{\text {hitung }}$ 15,62 $>F_{\text {tabel }}$ 3,35. Ini menunjukkan bahwa regresi linear ganda faktor lingkungan keluarga $\left(\mathrm{X}_{1}\right)$ dan aktivitas fisik $\left(\mathrm{X}_{2}\right)$ terhadap Kesegaran Jasmaniberarti (nyata).Dengan demikian hipotesis yang diajukan (Ha) dapat diterima. Selanjutnya diperoleh koefisien determinasi melalui koefisien korelasi dikuadratkan $\left(r^{2}\right)=(0,497)^{2}$ sebesar 0,2470. Artinya bahwa kedua variabel faktor lingkungan keluarga dan aktivitas fisik sebagai independent variabel memiliki kontribusi sebesar $24,70 \%$ terhadap Kesegaran Jasmanisebagai dependent variabel. Sedangkan sisanya diterangkan oleh variabel lain.

Hasil Pengujian hipotesis menunjukkan bahwa semua hipotesis yang diajukan diterima. Hal ini menunjukkan bahwa Faktor Lingkungan Keluarga dan Aktivitas Fisik mempunyai hubungan yang signifikan terhadap Kesegaran Jasmani anak Tunagrahita, baik sendiri-sendiri maupun secara bersama-sama.

Kontribusi Faktor Lingkungan Keluarga terhadap Kesegaran jasmani (hipotesis pertama) berdasarkan hasil analisis koofesien korelasinya didapat $r=0,1444$ yang menyatakan besar hubungan antara variable faktor lingkungan keluarga terhadap kesegaran jasmani anak tunagrahita. Sedangkan kontribusi variabel faktor lingkungan keluarga terhadap kesegaran jasmani anak tunagrahita sebesar 14,44\%. Hal ini berarti bahwa, apabila faktor lingkungan keluarga baik maka hasil kesegaran jasmani anak tunagrahita juga akan baik. Begitu sebaliknya apabila faktor lingkungan keluarga yang tidak kondusif maka kesegaran jasmani anak tunagrahita juga tidak akan baik. Hal ini sependapat yang di kemukakan oleh Patricia Adam (2010:273) lingkungan keluarga merupakan pihak yang sangat berperan penting terhadap proses perkembangan anak baik kegiatan-kegiatan baru maupun yang biasa.

Selanjutnya untuk mengenai hubungan fungsional antar variable yang mana skor pada suatu variable dapat digunakan untuk memprediksi skor pada variable lainnya dilakukan analisis regresi lenear sederhana. Dari hasil analisis diperoleh persamaan regresi $\hat{Y}=-2991,66+54,34$ X. Model persamaan regresi ini mengandung arti bahwa apabila faktor lingkungan keluarga ditingkatkan satu skor, maka kecendrungan kesegaran jasmani meningkat sebesar 54,34 skor pada konstanta 2991,66. 
Kontribusi aktivitas fisik terhadap kesegaran jasmani anak tunagrahita (hipotesis kedua), berdasarka hasil analisis kooefisien korelasi didapatkan $r=0,1576$ yang menyatakan besarnya hubungan antara variable aktivitas fisik dengan kesegaran jasmani anak tunagrahita. Sedangkan kontribusi aktivitas fisik terhadap kesegaran jasmani anak tunagrahita sebesar 15,76\%. Hal ini berarti bahwa, apabila aktivitas fisik anak tunagrahita tinggi maka kesegaran jasmani anak tunagrahita juga tinggi. Begitu sebaliknya apabila aktivitas fisik rendah maka kesegaran jasmani anak tunagrahita cendrung rendah. Terdapat kontribusi secara positif antara aktivitas fisik terhadap kesegaran jasmani anak tunagrahita. Hal ini sependapat yang dikemukakan Lutan, Rusli (2007:7) Aktivitas fisik aneka kegiatan yang gerakan tubuh yang dihasilkan oleh otot kerangka dan kegiatan itu mengeluarkan energi.

Selanjutnya untuk mengetahui hubungan fungsional antar variable yang mana skor pada suatu variable lainnya dilakukan analisis regresi linear sederhana. Dari hasil analisis diperoleh persamaan regresi $\hat{Y}=-1833,88+41,58 \mathrm{X}_{2}$. Model persamaan regresi ini mengandung arti bahwa apabila aktivitas fisik ditingkatkan satu skor, maka kecendrungan kesegaran jasmani anak tunagrahita meningkat sebesar sebesar 41,58 skor pada konstanta $-1833,88$.

Kontribusi antara faktor lingkungan keluarga dan aktivitas fisik secara bersamasama terhadap kesegaran jasmani (hipotesis ketiga), berdasarkan hasil analisis kooefisien korelasi ganda didapatkan 0,2470 yang menyatakan besar hubungan antara variabel faktor lingkungan keluarga dan aktivitas fisik secara bersama-sama dengan kesegaran jasmani anak tunagrahit. Sedangkan kontribusi variabel faktor lingkungan keluarga dan aktivitas fisik secara bersama-sama terhadap kesegaran jasmani anak tunagrahita sebesar 24,70\%. Akan tetapi dalam pengujian independeni antara variabel bebas dalam hubungan denganvariabel terikat yang dilakukan terdapat kontaminasi.Hal ini diduga aktivitas fisik juga dipengaruhi faktor lingkungan keluarga.Seperti yang dikatakan Efendi (2009:17) penyikapan dan perlakuan lingkungan keluarga memiliki kontribusi cukup kuat dalam memberikan warna terhadap perkembangan anak berkelainan. Patricia (2010:274) keterlibatan aktif keluarga dalam perkembangan anak berkelainan serta orang tua disekolah dan dirumah, diantara efek positifnya (a) membuat orang tua sadar akan apa yang akan mereka perbuat terhadap anaknya, bagaimana dan apa yanga mereka lakukan bersama di rumah mempunyai pengaruh dan berhubungan dengan pekerjaan anak di sekolah dan di rumah, (b) membuat orang tua menyadari bahwa apa yang mereka lakukan, sendiri atau bersama anaknya adalah penting bagi pembelajaran yang diterima anak, (c) membuat orang tua bisa lebih berinteraksi dengan anaknya dirumah serta mengetahui perkembangan psikososial anak.

Kesegaran jasmani merupakan kemampuan tubuh seseorang untuk melakukan tugas pekerjaan sehari-hari tanpa menimbulkan kelelahan yang berarti.Untuk dapat mencapai kesegaran jasmani yang prima seseorang perlu melakukan latihan fisik yang melibatkan kemampuan kesegaran jasmani dengan metoda yang benar.

Kesegaran jasmani pada hakikatnya berkenaan dengan kondisi fisik seseorang dalam melaksanakan tugas sehari-hari secara efisien dalam waktu yang relative lama, penuh validitas dan kewaspadaan tanpa mengalami kelelahan yang berarti dan masih cukup energy untuk bersantai pada waktu luang dan menghadapi hal-hal yang bersifat darurat.

Selanjutnya untuk mengetahui fungsional antar variabel yang mana skor pada dua atau lebih variabel bebas dapat digunakan untuk memprediksi skor pada variabel 
terikat dilakukan analisis regresi ganda. Dari hasil analisis diperoleh persamaan regresi $\hat{Y}=-6134,09+50,89+39,17$. Model persamaan regresi ini mengandung arti bahwa apabila aktivitas fisik ditingkatkan satu skor, maka kecendrungan kesegaran jasmani anak tunagrahita sebesar $-134,09+50,89+39,17$ skor pada konstanta $-6134,09$.

\section{KESIMPULAN}

Berdasarkan pada hasil analisis data dan pembahasan yang dijabarkan dapat diambil kesimpulan sebagai berikut:

1. Faktor Lingkungan Keluarga berkontribusi signifikan terhadap Kesegaran Jasmani Anak Tunagrahita.

2. Aktivitas Fisik berkontribusi signifikan terhadap Kesegaran Jasmanianak Tunagrahita.

3. Faktor Lingkungan Keluarga dan Aktivitas Fisik secara bersama-sama berkontribusi signifikan terhadap Kesegaran Jasmanipada Anak Tunagrahita SLB Negeri Pekanbaru.

\section{DAFTAR PUSTAKA}

Depdiknas. (2003). Pedoman penyelenggaraan Pendidikan Terpadu. Jakarta: Depdiknas.

Effendi, Mohammad. (2009). Pengantar Psikopedagogik Anak Berkalainan. Jakarta: PT. Bumi Aksara.

Lutan, Rusli. (1998). Belajar Keterampilan Motorik. Pengantar Teori dan Motorik. Jakarta: Depatemen Pendidikan Nasional.

Sugiyono. (2008). Metode Penelitian Pendidikan. Bandung: Alfabeta.

Undang-undang Sistem Pendidikan Nasional (UUSPN) No. 20 Tahun 2003. 